\title{
Aspects regarding extracurricular sport activities in schools from Bihor County, Romania
}

Authors' Contribution: A Study Design

B Data Collection

C Statistical Analysis

D Data Interpretation

E Manuscript Preparation

F Literature Search

G Funds Collection

\author{
Claudia Georgescu1 ABCDEF, Raluca Buhaș ${ }^{2}$ ABCDEF \\ ${ }^{1}$ School and University Sports Federation, Romania \\ 2 Faculty of Social Sciences, University of Oradea, Romania
}

\section{abstract}

Background: Participation in various extra-curricular sports activities is an important component of the professional activity of physical education teachers, regardless of whether we bring into discussion the organisation of such activities or training school teams in order to participate in these sports events.

Material and methods: On the one hand, the present paper approaches the way in which teachers are involved in extracurricular sports activities from a descriptive perspective. On the other hand, the paper captures physical education teachers' opinions on the way these sports competitions are organised and brings to attention some aspects that would need to be improved in this regard. Data were collected by a questionnaire addressed to physical education teachers from primary and secondary schools in Bihor County, Romania.

Results: Our results show the availability of physical education teachers to be involved in other extracurricular sports activities and to guide talented students toward various sports clubs.

Conclusions: Our research emphasises the need to improve certain aspects when organising local and regional sports competitions addressed to school teams as well as the importance to involve the public and private sector in these events.

Key words: extracurricular sports activities, sports competitions, physical education teachers, sport clubs, students.

\section{article details}

Article statistics: Word count: 2,817; Tables: 0; Figures: 8; References: 37

Received: June 2020; Accepted: August 2020; Published: November 2020

Full-text PDF: http://www.balticsportscience.com

Copyright @ Gdansk University of Physical Education and Sport, Poland

Indexation: Celdes, Clarivate Analytics Emerging Sources Citation Index (ESCI), CNKI Scholar (China National Knowledge Infrastructure), CNPIEC, De Gruyter - IBR (International Bibliography of Reviews of Scholarly Literature in the Humanities and Social Sciences), De Gruyter - IBZ (International Bibliography of Periodical Literature in the Humanities and Social Sciences), DOAJ, EBSCO - Central \& Eastern European Academic Source, EBSCO - SPORTDiscus, EBSCO Discovery Service, Google Scholar, Index Copernicus, J-Gate, Naviga (Softweco, Primo Central (ExLibris), ProQuest - Family Health, ProQuest - Health \& Medical Complete, ProQuest - Illustrata: Health Sciences, ProQuest - Nursing \& Allied Health Source, Summon (Serials Solutions/ProQuest, TDOne (TDNet), Ulrich's Periodicals Directory/ulrichsweb, WorldCat (OCLC)

Funding: This research received no specific grant from any funding agency in the public, commercial, or not-for-profit sectors.

Conflict of interests: Corresponding author: Authors have declared that no competing interest exists.

Raluca Buhaș, Universitatii street, no.1, postal code 410087, Oradea, Romania; phone: +40 773 797515; e-mail: ralubuhas@gmail.com

Open Access License: This is an open access article distributed under the terms of the Creative Commons Attribution-Non-Commercial-NoDerivatives 4.0 International (https://creativecommons.org/licenses/by-nc-nd/4.0/), which permits use, distribution and reproduction in any medium, provided the original work is properly cited, the use is non-commercial and is otherwise in compliance with the license. 


\section{INTRODUCTION}

The present paper addresses an important topic regarding the professional activity of physical education teachers, and the guidance of students with special physical qualities toward performance sports: teachers' involvement in extracurricular sports activities. The engagement in these extracurricular sports activities indicates great willingness shown by physical education teachers to discover young talents in sports and to motivate students to participate in sports competitions. First, a brief literature review is presented regarding the formal framework that supports the organisation of extracurricular sports activities in Romania. The statistical data available at local and national level presents the results obtained by school teams at such sports competitions. On the one hand, these results reveal the degree of teachers' involvement in organising these sports activities, but, on the other hand, they show the level of school teams' preparation in order to participate in such sports competitions. Eventually, some models of good practices regarding the organisation of sports competitions aiming school teams are briefly presented. Also, the methodological framework of the research is presented by pointing out the research objectives and method, as well as the data collection tool. Before discussing the research results, the respondents' socio-demographic profile is also briefly presented. Data are descriptively analysed, and research results are presented and discussed in detail. In the end, the main conclusions of the study are summarised.

\section{LITERATURE REVIEW. A SYNTHETIC FRAMEWORK}

The professional activity of physical education teachers implies much more aspects than simply conducting a physical education class in school. They participate in a series of activities outside the curriculum, mostly sports competitions [1-4]. These events are necessary because, as the years go by (the switch from primary to secondary school), the intensity and frequency of physical education classes decrease [5]. Various types of events were approached to increase the volume of physical activities among children [6]. Some of these activities are included in the school curriculum, but some of them are organised outside school curriculum [7, 8]. Studies have shown that physical activity carried out exclusively during classes mentioned by the school curriculum has limited effects [9] and it is considered to be less important than other subjects [10]. This fact suggests the need to approach sport also through alternative activities. In this regard, extracurricular sports activities developed using sports infrastructure and facilities in schools provide opportunities for students to be more active $[11,12]$. Since 2009, a series of studies have been carried out highlighting the importance of different types of sport, in general, as well as extracurricular physical activities [13-17]. Sports associations and clubs established in addition to school units are positive factors for organising and developing extracurricular sports activities and competitions; these activities give opportunities for less active students to be more involved in sports competitions [18-21]. The organisation of extracurricular activities requires additional financial and human resources. Physical education teachers need to have incentives to organise these events [22]. The benefits generated by these types of activities are diverse. They lead to the development of students' psycho-social characteristics, their behavioural motivation (physical activity is fun and offers benefits), positive cognition, affective and behavioural benefits, as well as increase their success in school [23, 24, 25]. These programs also help primary school children to feel more competent and physically confident and create the feeling that they are part of a team.

These extracurricular sports activities take place in an organised institutional framework. Extracurricular physical and sports activities are widespread in the European Union [26-28]. They take place outside school classes and are linked to competitions or health improving activities, organised in order to render physical education activities more accessible and attractive for students [29]. In addition to making physical education a compulsory discipline in the school curriculum, European Union countries are trying to 
encourage young people to play sports outside teaching hours, one of the benefits being their guidance performance sports [30]. Mainly, extracurricular activities are aimed at students and are developed outside the classroom curriculum [29]. Each EU member country settles its own form of organisation in this regard [31]. Activities are established at the governmental level, in a unitary way at the national level [32]. In Romania, extracurricular physical activities and sports are regulated by law [33]. According to regulations, the organisational forms of extracurricular physical activity and sports in primary schools include weekly sports competitions between classes, tourist activities, at least quarterly, sports activities organised through the school sports association within the National Olympics of School Sports, competitions or contests within each educational unit. For secondary school (gymnasium level), the organisational forms of extracurricular physical activity and sports include preparation of school sports teams, competitions, contests or championships within each educational unit or organised through the school sports associations within the National Olympics of School Sports, and so on. These activities are developed under the guidance of competent institutions at the central and county level. The National Olympics of School Sports as well as Gymnasium Olympics of the Federation of School and University Sports take place under the patronage of the Ministry of Education and Research [34, 35]. At the county level, Bihor County Directorate for Sports and Youth, in cooperation with Bihor County School Inspectorate, organises a sport event entitled "Bihor in motion", but also numerous county stages of national competitions [36, 37].

\section{MATERIAL AND METHOD}

Research objectives. Based on the study topic, the general research objective was to identify and describe extracurricular sports activities developed by physical education teachers in primary and secondary schools from Bihor county. Based on the general objective, the following specific research objectives were outlined:

SO1. to identify the type of extracurricular sports activities developed by teachers, SO2. to identify and describe the participation in sports competitions with school teams, SO3. to evaluate the organisation of extracurricular sports competitions addressed to school teams.

Research method and data collection tool. We used a quantitative research strategy, with a developed direct survey and data collected using a questionnaire. The questionnaire included several questions regarding the organisation and development of physical education classes in rural and urban schools from Bihor county, Romania. Data were collected between September-December 2019.

The subjects of the study were physical education teachers specialised in a specific sports branch who teach physical education classes at primary and secondary levels in urban and rural schools from Bihor county. The total number of respondents was 227.

\section{RESULTS AND DISCUSSION}

\section{SOCIO-DEMOGRAPHIC PROFILE OF RESPONDENTS}

Gender. Most respondents are male $-76.4 \%$. Only $23.6 \%$ of respondents declare themselves as being female. This disproportion of respondents in terms of gender distribution may be due to the type of professional activity: respondents are physical education teachers, so men are more prone to physical activities performed outdoors.

Age. Respondents range between 22 and 65 years old. The mean value of respondents' age is 38.7 years. This highlights a trend for younger physical education teachers in schools 
from Bihor county, while young people are more and more attracted to this profession. Young age is an advantage when we refer to the engagement of teachers in extracurricular sports activities.

Teaching certification degree. In Romanian education, teachers are stimulated to obtain higher teaching certification degrees. Of course, the degree diploma is conditioned by seniority as a teacher, and also by teachers' involvement in other activities outside school curriculum. Also, a $\mathrm{PhD}$ diploma provides a certain income for the entire period of subsequent activity. Many respondents (45.8\%) declare that they obtained the teaching certification degree 1, while $21.6 \%$ declare that they have the 2 nd degree or have a permanent teaching certificate for undergraduate education. Only $1.3 \%$ of subjects state that they have a PhD diploma (Figure 1). These facts indicate a high concern among teachers in obtaining teaching certification degrees, which will be further reflected in higher incomes.

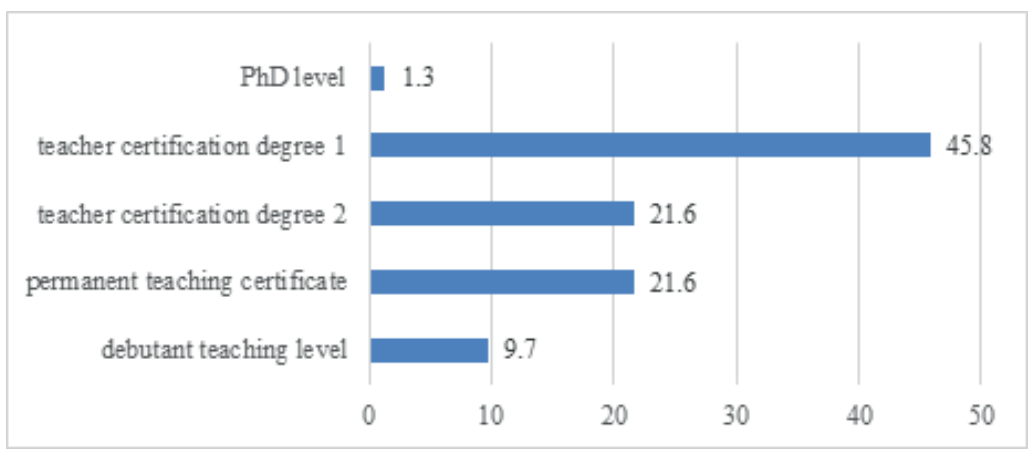

Fig. 1. Respondents' teaching certification degree (\%)

The average value in terms of respondents' seniority in education is 13.36 years. This highlights the fact that teachers take their exams in time in order to obtain teaching certification degrees, being stimulated by the increase in their incomes. Most respondents are employed for an undetermined period on the teaching positions (75.8\%), which gives them stability and security, aspects that can positively influence their decision to get involved in extracurricular activities.

Most respondents (84.7\%) state that they teach in primary level schools, while only $15.3 \%$ of them teach at the middle-school level (Figure 2). This aspect highlights the fact that the majority of them teach in schools from rural areas, where there are more classes at the primary level. Secondary level schools are mostly grouped in the urban area.

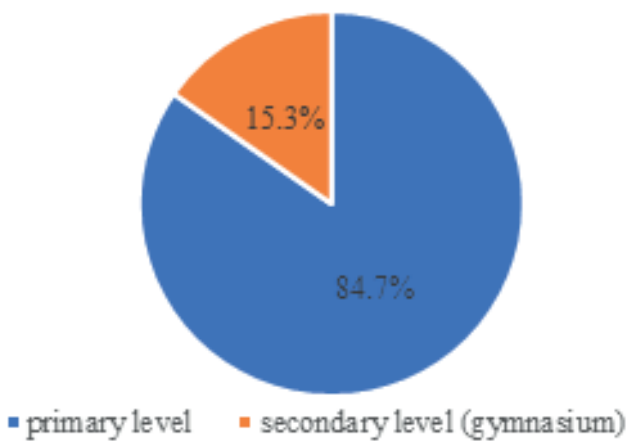

Fig. 2. Educational level at which the subjects teach (\%) 
The development of extracurricular sports activities is conditioned by the sport specialisation of physical education teachers. Many respondents are specialised in football (36.6\%), 6.3\% of them specialise in volleyball, $5.8 \%$ in basketball and $13.8 \%$ in handball. If we sum up these four sports specialisations, we have a value that is much higher $(62.5 \%)$ than the sum of all other specialisations declared (37.5\%) (Figure 3). Most teachers specialise in football, handball, volleyball and basketball. This situation is determined, among others, by the majors offered by profile higher education institutions, by the promotion of these sports games in media, and also by the possibility to provide and settle necessary infrastructure and facilities for these sports at school level. These aspects also influence the type of sport that will develop with priority during extracurricular activities.

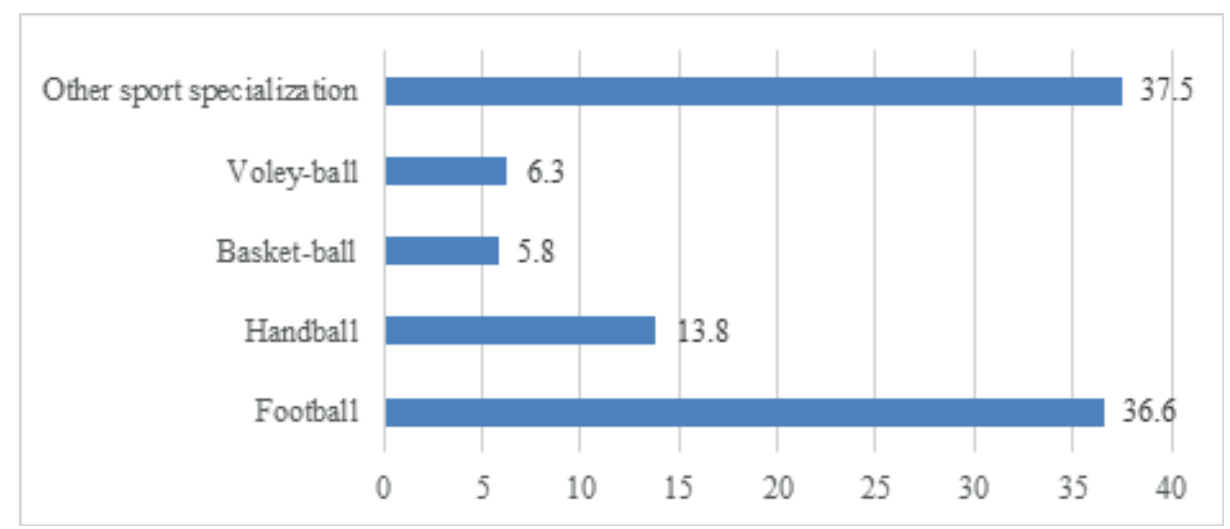

Fig. 3. Respondents' professional specialisation (\%)

\section{EXTRACURRICULAR SPORTS ACTIVITIES}

As mentioned before, there is an increasing concern, at the European and national level, to organise and develop extracurricular sports activities. The number of physical education classes included in the school curriculum in Romania is insufficient; therefore, the recommendations would be to develop sports activities and competitions beside these compulsory classes. This implies big amounts of human, material and time resources, which are not always available. Teachers are the ones who need to be motivated to engage in these activities. If teachers are engaged in these activities, they accumulate points, diplomas, distinctions, which help them to complete their professional file.

In this context, most teachers who were included in our study (79.7\%) state that they are involved in organising extracurricular sports activities. Only $20.3 \%$ of them are not engaged in such events (Figure 4). Usually, physical education teachers are involved in the following types of extracurricular sports activities: organising various sports competitions in the school they teach, participation in sports competitions with school teams, preparing school teams to participate in sports competitions.

The fact that physical education teachers specialise in only one branch of sport does not exclude their involvement in activities that include other sports. Most respondents (74.4\%) train at least one school team to at least one sports game (Figure 5). The involvement of physical education teachers in various events related to extracurricular sports activities. However, the most present sports games at the school team level are: football, handball, basketball, volleyball, athletics. Less frequent are school team of oina (a national Romanian sports game), rugby-tag, women's football, badminton, table tennis, chess. However, the presence of these sports in extracurricular activities must be pointed out. 


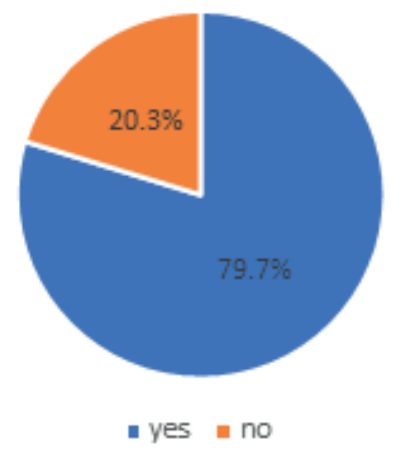

Fig. 4. Teachers' degree of engagement in organising extracurricular sports activities

Fig. 5. Do you train school teams for sports games?

According to our research results, subjects declare that they participated between 20132018 with school teams in the following types of sports competitions: "Bihor in motion", the National Olympics of School Sports (ONSS in Romanian), Gymnasium Olympics (OG in Romanian), Special Olympics, as well as in other regional competitions. These events are centrally organised, at the national level (ONSS, OG, Special Olympics), as well as by local initiatives, "Bihor in motion", an action developed by the County Directorate for Youth and Sports, together with the Bihor County School Inspectorate. This sports competition was very well received at the national level, being the basis of another competition - "Romania in motion" - organised by the Ministry of Youth and Sports. The results obtained with school teams in these sports competitions are high; most school teams obtained 1st, 2nd, 3rd places at different stages of the competitions (local level, county level, regional level, national level). Other places obtained are rarely mentioned.

Most respondents (65\%) consider that the number of competitions organised for school representatives in Bihor county is enough (Figure 6). An average of four annual extracurricular activities, organised at the county level and finalised at the national level, are considered to be sufficient. These activities cover the structure of the school year very well, and from an extracurricular perspective are considered to be sufficient in order to meet students' needs for competition and develop their competition spirit but also to help strengthen self-esteem and social relations. 


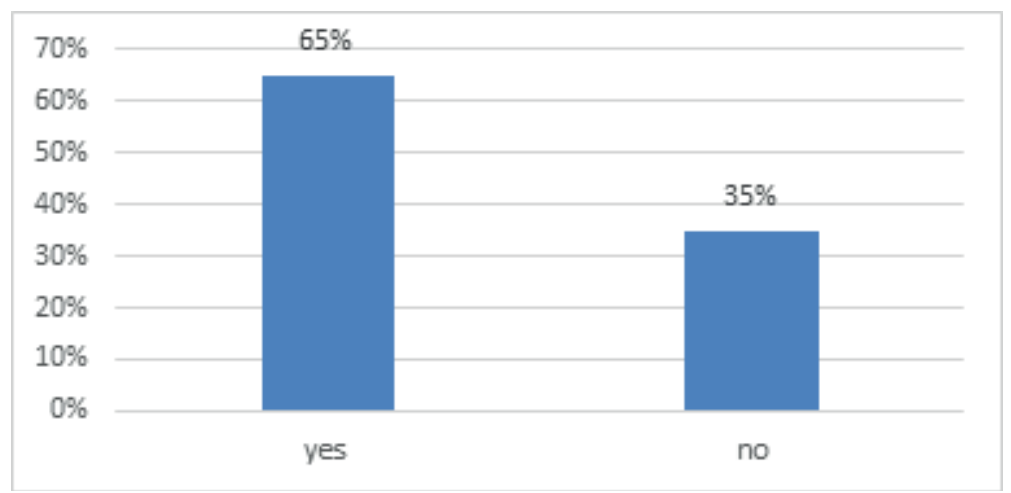

Fig. 6. Do you think the number of sports competitions is enough?

These extracurricular activities follow a tradition in their development. They take place annually, being well structured and promoted. There are departments of central and local public institutions engaged in the organisation of these sports events. Partnerships are also established between these institutions and media institutions in order to promote and support these activities.

Most respondents considered that these sports competitions were properly organised (73.2\%) (Figure 7). The percentage of those who were not satisfied in this regard is rather low. This situation may be generated due to the lack of positive results at these sports competitions, which naturally generates dissatisfaction. However, the fact that there is also dissatisfaction in this regard is beneficial, because this situation can lead to a dialogue in order to improve the way these sports competitions are organised.

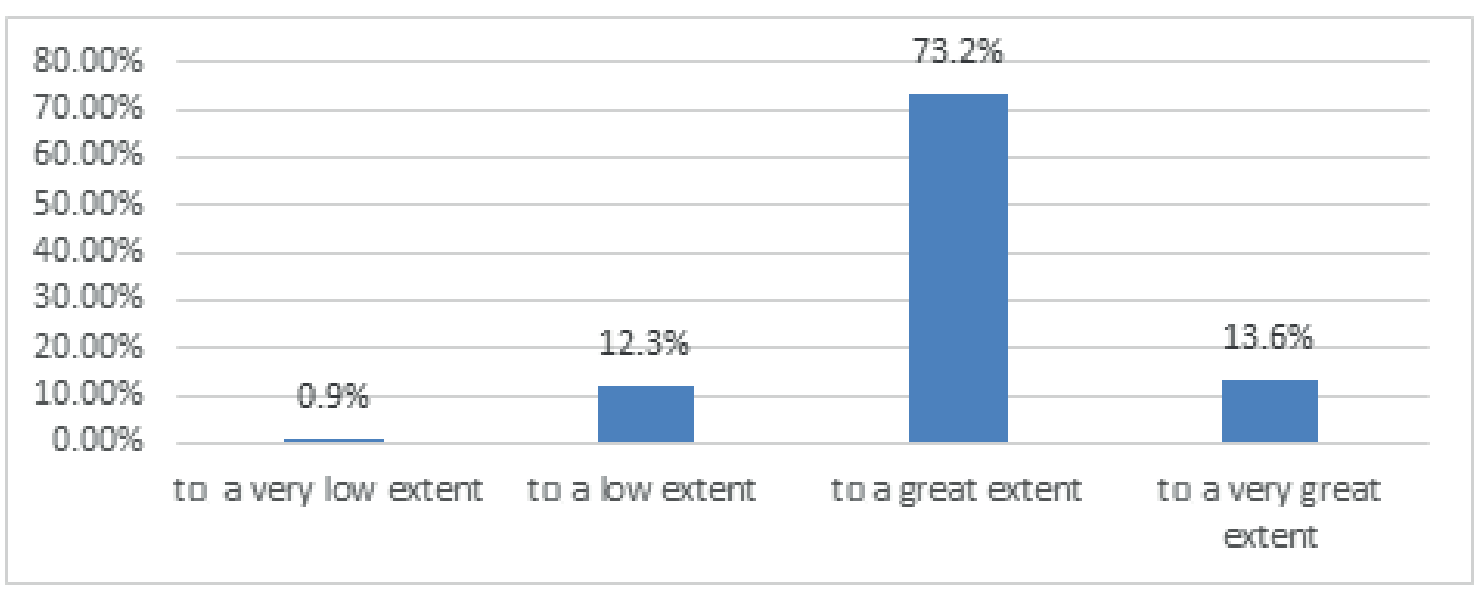

Fig. 7. To what extent do you think these sports competitions were properly organised?

Regarding the improvements that should be made regarding sports competitions for school representatives, respondents mainly mention issues related to organisational aspects. Physical education teachers especially emphasise the quality of arbitration, provided medical assistance, higher awards for participants, higher quality of the sports infrastructures where these competitions take place. Respondents also believe that the involvement of a wider range of social actors in the organisation of these competitions (various local authorities, the private sector, sports federations) would raise the quality level of these competitions. 
Most often, sports competitions for school representatives were organised by local authorities and institutions at the county and/or national level: County Directorate for Sports and Youth, Bihor County School Inspectorate, City Hall, Ministry of Education. In addition to these authorities and institutions that organise and support the development of such sports competitions, respondents consider that also other social actors should be involved in these events, such as sports associations and federations, the County Council, sports clubs, NGOs, private companies.

Extracurricular sports competitions must be the selection basis for school sports and performance sports. It is expected that physical education teachers participating in these activities to observe the sporting quality of competing students. Students should be directed toward youth organisations, school sports clubs, and also toward professional sports clubs.

The majority of respondents (96\%) state that they usually guide students with special sporting qualities toward various sports clubs (Figure 8). Our research results showed that each physical education teacher who participates in such extracurricular sport activities during 2013-2018, guided an average of 14 students to performance sports. This percentage is considered to be high, which indicates teachers' pursuit to identify potential talented students for performance sports.

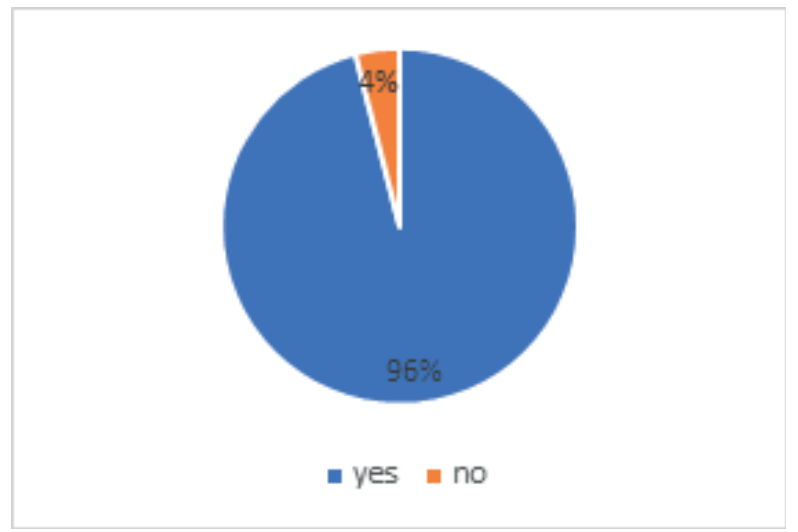

Fig. 8. Do you guide talented students toward any sports club?

The present research was conducted only in primary and secondary schools from only one county in Romania. This is a major research limitation due to its lack of representativeness al national level. Future research could analyse the situation regarding extracurricular sports activities also in high schools from Bihor county, but also from other counties.

\section{CONCLUSIONS}

Physical education teachers are widely involved in extracurricular sports activities, such as organising various sport events and physical activities, training school sports teams and participating in various sports competitions at the local, regional and national level. We should point out the positive results and high rankings achieved by most of those who participated in these sports competitions. Physical education teachers tend to train school teams in various sports, but mainly in football, handball, basketball, athletics, volleyball, sports of great interest to students and which do not require much effort to prepare and provide the necessary infrastructure and facilities.

Overall, sports competitions addressed to school teams are evaluated by teachers as being properly organised and sufficient, as frequency, in order to meet students' needs. 
However, improvements can be made at the organisational level, especially as regards arbitration, health assistance or sports infrastructure. A higher level of involvement of various authorities, institutions, clubs and sports federations in organising and developing such sports competitions at local level it is also desirable. Also, physical education teachers tend to discover and guide as many talented students as possible toward different sports clubs or performance sports regardless of the type of sports game.

\section{REFERENCES}

[1] Powers SH, Conway LT, McKenzie LT, Sallis FJ, Marshall JS. Participation in extracurricular physical activity programs at middle schools. Res Q Exerc Sport. 2002;72(2):187-192. https://doi.org/10.1080/02701367.2002.10609007

[2] Heidorn B. An Outside of school physical activity requirement for physical education. Strategies. 2016;29(5):42-47. https://doi.org/10.1080/08924562.2016.1206739

[3] Lyyra N, Leskinen E, Heikinaro-Johansson P. Factorial Validity and reliability and the curricular goals in physical education questionnaire. Measur Phys Educ Exerc Sci. 2015;19(2):69-79. https://doi.org/10.1080/1091367X.2015.1038822

[4] McKenzie LT, Lounsbery AFM. Physical education teacher effectiveness in a public health context. Res Q Exerc Sport. 2013;84(4):419-430. https://doi.org/10.1080/02701367.2013.844025

[5] Dumith SC, Gigante DP, Domingues MR, Kohl HW. Physical activity change during adolescence: A systematic review and a pooled analysis. Int J Epidemiol. 2011;40(3):685-698. https://doi.org/10.1093/ije/dyq272

[6] Ilies DC, Buhas R, Ilies M, et al. Sport Activities and Leisure in Nature 2000 Protected Area aRed Valley, Romania. J Environ Protect Ecology. 2018a;19(1):367-372.

[7] Dobbins M, Husson H, DeCorby K, LaRocca RL. School-based physical activity programs for promoting physical activity and fitness in children and adolescents aged 6 to 18. Cochrane Database Syst. Rev. (online). 2013;2. [Available at https://www.cochrane.org/CD007651/ENDOC_school-based-physical-activity-programs-for-promoting-physicalactivity-and-fitness-in-children-and-adolescents-aged-6-to-18] [Accessed on 13 April 2020].

[8] van Sluijs EM, McMinn AM, Griffin SJ. Effectiveness of interventions to promote physical activity in children and $\square$ adolescents: systematic review of controlled trials. The BMJ. 2007;335:703. https://doi.org/10.1136/bmj.39320.843947.BE

[9] Jago R, Baranowski T. Non-curricular approaches for increasing physical activity in youth: A review. Prev Med. 2004;39(1):157-163. https://doi.org/10.1016/j.ypmed.2004.01.014

[10] Olszewski-Strzyżowski DJ. European societies' access to sport - the European Union actions. GeoSport for Society. 2018;9(2):71-81. [Available at http://geosport.uoradea.ro/2018 2/2018 2 GSS Olszewski 18.09.03.040.pdf]. [Accessed on 7 April 2020].

[11] Onet A, Ilies DC, Buhas S, Rahota D, Ilies A, Baias S, Marcu F, Herman GV. Microbial air contamination in indoor environment of University sports hall. J Environ Protect Ecology. 2018;19(2):694-703.

[12] Ilies DC, Buhas R, Ilies A, et al. Indoor air quality issues. Case study: The multipurpose sports hall of the University of Oradea. Environ Eng Management J. 2018b;17(12):2999-3005. https://doi.org/10.30638/eemj.2018.300

[13] Beets MW, Beighle A, Erwin HE, Huberty JL. After-school program impact on physical activity and fitness: A metaanalysis. Am J Prev Med. 2009;36(6):527-537. https://doi.org/10.1016/j.amepre.2009.01.033

[14] Pate RR, O'Neill JR. After-school interventions to increase physical activity among youth. Br J Sports Med. 2009;43(1):14-18. https://doi.org/10.1136/bjsm.2008.055517

[15] Huberty JL, Dinkel DM, Beets MW. Evaluation of GoGirlGo! A practitioner based program to improve physical activity. The BMC Public Health. 2014;14:118. https://doi.org/10.1186/1471-2458-14-118

[16] Gortmaker SL, Lee RM, Mozaffarian RS, et al. Effect of an after-school intervention on increases in children's physical activity. Med Sci Sports Exerc. 2012;44(3):450-457. https://doi.org/10.1249/MSS.0b013e3182300128

[17] Morar C, Pop, AC. Water, tourism and sport. A conceptual approach. GeoJournal of Tourism \& Geosites. 2016;18(2):249258. [Available at http://gtg.webhost.uoradea.ro/PDF/GTG-2-2016/208_Morar.pdf] [Accessed on 23 April 2020].

[18] Davies B, Wood L, Banfield K, Edwards MJ, Jago R. The provision of active after-school clubs for children in English primary schools: implications for increasing children's physical activity. Open J Prev Med. 2014;4:598-605. https:// doi.org/10.4236/ojpm.2014.47069

[19] Buhas S, Herman VG, Stef M. Aspects regarding speed development in football game in 12-14 years old children. GeoSport for Society. 2018;8(1):21-30.

[20] Dragos P, Lucaciu G, Dinis I, Stef-Gavris M, Szabo-Alexi P, Buhas S. Concepts Concerning the Content of Children's Training in Some Sport Games. Proceedings of the 4th International Conference of the Universitaria Consortium (ICU 2018): The Impact of Sport and Physical Education Science on Today's Society. 2018a;67-72.

[21] Scutti G, Wendt JA. Football and Geopolitics. GeoSport for Society. 2016;5(2):100-106.

[22] Ratcliff NJ, Jones CR, Vaden R, Sheehan H, Hunt GH. Paraprofessionals in early childhood classrooms: an examination of duties and expectations. Eary Years. 2011;31(2):163-179. https://doi.org/10.1080/09575146.2011.576333

[23] Baranowski T, Jago R. Understanding mechanisms of change in children's physical activity programs. Exerc Sport Sci Rev. 2005;33(4):163-168. https://doi.org/10.1097/00003677-200510000-00003

[24] Sebire SJ, Jago R, Fox KR, Edwards MJ, Thompson JL. Testing a self-determination theory model of children's physical activity motivation: a cross-sectional study. Int J Behav Nutr Phys Act. 2013;10:111. https://doi.org/10.1186/14795868-10-111

[25] Ostojic N, Plavsa J, Vujko A. Students' attitude and effects of sport and recreational tourism on success in schools. Geojournal of Tourism and Geosites. 2014;14(2):142-149. [Available at http://gtg.webhost.uoradea.ro/PDF/GTG-2 2014/4_151_Vujko.pdf]. [Accessed on 5 April 2020]. 
[26] Ilies A, Dehoorne O, Wendt JA, Kozma G. For Geography and Sport, Sport Geography or Geography of Sport. GeoSport for Society. 2014;1(1-2):7-18.

[27] Jochimek M, Krokosz D, Lipowski M. Physical activity and sport as a protective factor against health-threatening experiments with adulthood. Balt J Health Phys Activ. 2017;9(4):112-124. https://doi.org/10.29359/BJHPA.09.4.09

[28] Ratkowski W, Ratkowska J. Sports events as a determinant of sport tourism. Balt J Health Phys Act. 2018;10(1):8694. https://doi.org/10.29359/BJHPA.10.1.09

[29] European Commission. Physical education and sport at school in Europe. Eurydice Report. 2013. [Available at https:// eacea.ec.europa.eu/national-policies/eurydice/content/physical-education-and-sport-school-europe_en] [Accessed on 3 April 2020].

[30] Dehoorne O, Wendt JA, Mikhailov A, Berdenov Z, Ilies A. Cartographic representation of a sports (football) competition - UEFA Youth League (2013-2019). Geosport for Society. 2019;11(2):86-100. https://doi.org/10.30892/gss.1104-051

[31] Marcu V, Buhas S. Sport Organizations - Management and Science. Procedia - Social and Behavioral Sciences. 2014;117:678-682. https://doi.org/10.1016/j.sbspro.2014.02.281

[32] Dragos P, Lucaciu G, Trifa I, Stef Gavris M, Szabo-Alexi P, Buhas S. Aspects Regarding the Influence of Communication on the Motivation of Employees in Some Sports Organizations. Proceedings of the 4th International Conference of the Universitaria Consortium (ICU 2018): The Impact of Sports and Physical Education Science on Today's Society. 2018b;73-77.

[33] Ministry of Education, Research, Youth and Sports (Romania). Metodologia organizarii si desfasurarii activitatilor de eductie fizica si sport in invatamantul preuniversitar din 06.03.2012 [Methodology for organizing and developing physical education and sports activities in pre-university education from 06.03.2012]. [Available at https://lege5.ro/ Gratuit/gmytgnbrha/metodologia-organizarii-si-desfasurarii-activitatilor-de-educatie-fizica-si-sport-in-invatamantulpreuniversitar-din-06032012] [Accessed on 18 April 2020]. Romanian.

[34] Ministry of Education (Romania). Calendarul competitiilor sportive scolare nationale anul scolar 2018- 2019 [Calendar of national school sports competitions for school year 2018-2019]. [Available at https://www.edu.ro/sites/default/files/ fisiere\%20articole/Calendarul\%200G\%202018-2019.pdf]. [Accessed on 18 April 2020]. Romanian.

[35] Federatia Sportului Scolar si Universitar (Romania) [Federation of School and University Sports]. Calendar Sport Scolar [School Sports Calendar]. 2020. [Available at https://fssu.ro/calendar-sport-scolar/\#]. [Accessed on 7 April 2020]. Romanian.

[36] Inspectoratul Scolar Judetean Bihor (Romania). [School Inspectorate of Bihor County]. Calendar competitional ONSS - judetean - regional - national, 2019-2020 [Competitive calendar - ONSS - county - regional - national, 2019 2020]. 2020. [Available at https://www.isjbihor.ro/curriculum/educatie-fizica-si-sport/1532-calendar-competitionalonss-judetean-regional-national-2019-2020]. [Accessed on 7 April 2020]. Romanian.

[37] Mihalca F. "Editia 2018 a "Bihorului in miscare" si-a desemnat castigatorii [The 2018 edition of "Bihor in motion" announced its winners]. In: e-Bihoreanul (daily newspaper article). November 18, 2018. [Available at https://www. ebihoreanul.ro/stiri/ultima-or-31-2/editia-2018-a-bihorului-in-miscare-si-a-desemnat-castigatorii-145417.html]. [Accessed on 7 April 2020]. Romanian. 